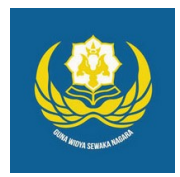

Jurnal Analogi Hukum

Journal Homepage: https://ejournal.warmadewa.ac.id/index.php/analogihukum

\title{
Perlindungan Konsumen Terhadap Tindakan Pemadaman Listrik yang dilakukan Secara Sepihak Oleh PT. PLN (Persero) UP3 Bali Selatan
}

\author{
I Gede Dharma Kusuma*, I Nyoman Putu Budiartha dan Ida Ayu Putu Widiati \\ Fakultas Hukum, Universitas Warmadewa, Denpasar, Bali-Indonesia \\ *gddharmakusuma@gmail.com
}

\begin{abstract}
How To Cite:
Kusuma, I. G. D., Budiartha, I. N. P., \& Widiati, I. A. P. (2021). Perlindungan Konsumen Terhadap Tindakan Pemadaman Listrik yang dilakukan Secara Sepihak Oleh PT. PLN (Persero) UP3 Bali Selatan. Jurnal Analogi Hukum. 3 (2). 230-234. Doi: https:// doi.org/10.22225/ah.3.2.2021.230-234

Abstract - Indonesia is a country consisting of several islands and every region that requires electricity as a daily need and long -term needs, the current situation many people complain about the services provided by $P L N$ is a power outage without prior notice. The numb er of public complaints related to power outages makes PLN in improving the organizational structure, especially in the sector of coordination between workers. The government in terms of providing protection to the community in terms of obtaining electricity supply is enough to make consumer protection regulations in which there is a right and obligation of consumers to get justice and obliged to conduct appeals from the government in an effort to prevent criminal acts in accordance with positive laws appli cable in Indonesia. The government is questioning the field workers from the PLN who deliberately or unintentionally do not inform the public of this turn -based power outage and it should be the $P L N$ to give a reprimand for its workers who do not carry out orders in accordance with the SOP applicable in the company.
\end{abstract}

Keywords: Consumer Protection; Power Outages; Unilaterally.

\begin{abstract}
Abstrak-Indonesia merupakan negara yang terdiri dari beberapa pulau dan setiap wilayah yang ada memerlukan tenaga listrik sebagai kebutuhan sehari - hari maupun kebutuhan jangka panjang, keadaan yang ada saat ini banyak masyarakat mengeluh terhadap pelayanan yang diberikan pihak PLN yaitu pemadaman listrik tanpa pemberitahuan terlebih dahulu. Banyaknya keluhan masyarakat berkaitan dengan pemadaman listrik membuat pihak PLN kelimpungan dalam membenahi struktur organisasi terutama di sektor koordinasi antar pekerja. Pemerintah dalam hal memberikan perlindungan kepada masyarakat dalam hal mendapatkan pasokan listrik cukup membuat peraturan perlindungan konsumen yang didalamnya terdapat hak dan kewajiban konsumen untuk mendapatkan keadilan dan berkewajiban melakukan himbauan dari pemerintah dalam upaya mencegah terjadinya tindak pidana sesuai dengan hukum positif yang berlaku di Indonesia. Pemerintah mengatasi para pekerja lapangan dari pihak PLN yang secara sengaja atau tidak disengaja tidak memberitahu masyarakat pemad aman listrik bergilir ini dan sudah seharusnya pihak PLN memberikan teguran bagi para pekerjanya yang tidak menjalankan perintah sesuai SOP yang berlaku di perusahaan.
\end{abstract}

Kata Kunci: Perlindungan Konsumen; Pemadaman Listrik; Secara Sepihak.

\section{Pendahuluan}

Indonesia merupakan negara yang terdiri dari beberapa pulau dan setiap wilayah yang ada memerlukan tenaga listrik sebagai kebutuhan sehari-hari maupun kebutuhan jangka panjang, keadaan yang ada saat ini banyak masyarakat mengeluh terhadap pelayanan yang diberikan pihak PLN yaitu pemadaman listrik tanpa pemberitahuan terlebih dahulu. Banyaknya keluhan masyarakat berkaitan dengan pemadaman listrik membuat pihak PLN kelimpungan dalam membenahi struktur organisasi terutama di sektor koordinasi antar pekerja. Pemerintah dalam hal memberikan perlindungan kepada masyarakat dalam hal mendapatkan pasokan listrik cukup membuat peraturan perlindungan konsumen 
yang didalamnya terdapat hak dan kewajiban konsumen untuk mendapatkan keadilan dan berkewajiban melakukan himbauan dari pemerintah dalam upaya mencegah terjadinya tindak pidana sesuai dengan hukum positif yang berlaku di Indonesia (Nasution, 2003).

Dalam memajukan perekonomian pemerintah menyiapkan lapangan pekerjaan kepada semua masyarakat namun tidak semua bisa bekerja di pemerintahan karena berbagai alasan salah satunya pendidikan minimal dan usia, semakin tua usia semakin tidak diterima seseorang untuk bekerja di perusahaan atau pemerintahan karena ada yang namanya fase produktif dan tidaknya seseorang. Na mun tidak semua masyarakat Indonesia menyerah dengan keadaan beberapa diantara membuka usaha untuk bisa melanjutkan kegiatan yang dapat menghasilkan sesuatu untuk menghidupi dirinya dan keluarganya.

Dengan berkembangnya teknologi maka bukan dari sektor perekonomiannya saja yang berkembang melainkan dari segi koordinasi juga. Salah satu kesalahan di bidang komunikasi pihak PLN adalah salah komunikasi antara atasan dan pekerja lapangan berkaitan dengan pemadaman listrik di masyarakat. Kejadian ini membuat ban yak orang merasa dirugikan karena tanpa pemberitahuan masyarakat yang bekerja tidak bisa bekerja penuh kerena terkendala pemadaman listrik dan sebagian besar masyarakat saat ini bekerja menggunakan laptop atau server yang terkait antara satu dan lainnya.

Pekerjaan merupakan suatu keharusan yang harus dilakukan setiap manusia, tujuannya sendiri untuk memenuhi kebutuhan dirinya dan keluarganya jika sudah memiliki keluarga. Selain memenuhi kebutuhan pekerjaan juga membuat seseorang menambah wawasan dan pergaul an dengan orang - orang baru yang ditemui di dunia kerja. Dengan bekerja seseorang dapat menghilangkan penat yang dia dapat di lingkungan keluarganya dan sebagai wadah untuk meniti karir namun terkadang jika bekerja tidak sepenuh hati maka akan sering terj adi kesalahan terutama pada komunikasi, setiap orang berhak menentukan pilihannya untuk bekerja dan setiap pemimpin wajib mengetahui kinerja karyawan dan masalah yang dihadapi karyawannya agar tidak sampai merugikan orang lain terutama yang berkaitan dengan perusahaan (Abdullah, 2010).

Menurut Pasal 1620 KUHP, perjanjian kerja adalah hasil dari perjanjian antara pengusaha dan pekerja untuk membangun hubungan kerja, dimana karyawan majikan terikat satu sama lain selama periode tertentu untuk melakukan pekerjaan tertentu oleh mendapatkan upah tertentu sesuai konsepnya. Dengan adanya kontrak kerja ini, baik majikan maupun pekerja tidak dapat memberikan perintah dan melakukan pekerjaan sewenang wenang, tetapi harus sesuai dengan ketentuan kontrak kerja.

Dewasa ini banyak para pekerja yang meski sudah mendapatkan penghasilan dari perusahaan yang mempekerjakannya masih memiliki kekurangan dana untuk memenuhi kebutuhan hidupnya dan keluarganya. Berbagai alasan yang ada seperti apa yang dikerjakan tidak sesu ai upah sampai tidak sesuai kemampuan namun tetap melakukan pekerjaan tersebut yang membuat pekerja tidak betah dalam bekerja. Semakin seseorang melakukan pekerjaan tidak dengan keikhlasan dan keinginan maka semakin berat dan susah pekerjaan yang dilakukan.

Banyaknya orang yang membutuhkan pekerjaan membuat persaingan di tempat kerja juga semakin ketat ditambah sedikitnya perusahaan yang membuka lowongan untuk para pekerja membuat banyak masyarakat yang menganggur sembari berharap adanya lowongan pekerjaan yang dibuka. Para pekerja yang sudah mendapat pekerjaan harus melakukan pekerjaan sebaik mungkin dan tidak melanggar SOP yang berlaku supaya mempertahankan jabatannya dan meminimalisir terjadinya pemutusan hubungan kerja. Melihat peluang yang ada saat ini penjualan produk obral online menjadi sampingan tersendiri bagi beberapa orang tidak terkecuali para pekerja yang tidak lagi mendapatkan pekerjaan.

Bagi pihak masyarakat terjadinya pemadaman listrik merasa dirugikan karena mengganggu efektivitas kerja, mem buang waktu menunggu listrik menyala untuk bisa melanjutkan pekerjaan dan meminta pertanggungjawaban dari pihak PLN agar masalah seperti ini tidak terulang lagi. Para pekerja yang sudah mendapat pekerjaan harus melakukan pekerjaan sebaik mungkin dan tidak melanggar SOP yang berlaku supaya mempertahankan jabatannya dan meminimalisir terjadinya pemutusan hubungan kerja. Namun terkadang sebaik apapun pekerjaan yang dilakukan ada saja ketidakcocokan antar sesama karyawan atau dengan pimpinan perusahaan membuat seorang karyawan harus banyak bersabar demi mempertahankan pekerjaan karena sulitnya saat ini mencari pekerjaan.

Rumusan masalah dalam penelitian ini 
adalah Bagaimana pengaturan perlindungan hukum konsumen pengguna listrik pada PT. PLN (Persero) UP3 Bali Selatan? Dan Bagaimana upaya hukum yang dapat dilakukan oleh konsumen pengguna listrik apabila terjadi pemadaman listrik secara sepihak oleh PT. PLN Persero UP3 Bali Selatan?

\section{Metode}

Penelitian skripsi ini dilakukan dengan mencari data melalui penelitian langsung kelapangan dan mengkaitkan dengan buku ilmu hukum sesuai permasalahan yang diangkat serta mengaitkan dengan perundang - undangan yang berlaku saat ini. Dari segi hukum penelitian ini termasuk penelitian empiris. Penulis mengkaitkan dengan peraturan yang berlaku dan tidak menyimpang dari undang undang dasar. Pendekatan penelitian dengan cara wawancara dan mengkaji data dari berbagai buku hukum dan berpatokan pada undang - undang sebagai dasar penulisan skripsi. Penelitian ini bertujuan mencari informasi yang akurat dengan mempelajari gejala masyarakat untuk mendapatkan data yang sebenar - benarnya. Dengan demikian data dapat digabungkan dengan berbagai referensi buku hukum yang terkait dan menghasilkan skripsi yang tidak melenceng dari hukum positif (Ahmad, 2008). Penulis meneliti kasus ini menggunakan metode empiris. Dimana dalam pengerjaannya penulis mengumpulkan informasi dengan wawancara dan menelaah dan menganalisa buku - buku hukum yang didasari peraturan- peraturan hukum yang berlaku di Indonesia.

\section{Hasil dan Pembahasan}

\section{Pengaturan Perlindungan Hukum Terhadap Konsumen Pengguna Listrik Pada PT. PLN (Persero) UP3 Bali Selatan}

Dalam melakukan pekerjaan seseorang berhak mendapatkan kebebasan untuk berinovasi dan melakukan hal yang diinginkan namun sesuai dengan batasan yang ada, ada beberapa prinsip dalam melakukan pekerjaan:

1. Prinsip kebebasan merupakan prinsip dasar semua orang, teruntuk yang bekerja maupun yang tidak bekerja. Segala aktivitas bebas dilakukan namun semua sesuai dengan etika dan tidak merugikan pihak lain. Dalam melakukan pekerjaan seorang bebas mengajukan pendapat, menyuarakan ketidaksetujuan akan putusan yang di buat, semua biasa terjadi karena dengan perbedaan pemikiran membuat suatu perusahaan semakin solid.

2. Prinsip ketidaksetaraan, merupakan prinsip yang sudah terdoktrin pada beberapa orang khususnya dalam pekerjaan. Membeda bedakan pergaulan sesuai dengan ka sta atau materi. Hal seperti kadang membuat beberapa orang risih dan tidak jarang menjadi korban seperti bully atau penindasan. Kedua prinsip ini saling berdampingan karena terjadi disetiap aktivitas yang dilakukan dan ada dilingkungan masing - masing orang.

Setiap hari terjadi dua hal yang saling berlawanan tersebut tinggal masing - masing individu yang bebas memilih prinsip mana yang digunakan dalam melakukan aktivitas sehari hari termasuk dalam lingkungan sekitar. Perbedaan prinsip tersebut membuat neg ara Indonesia sampai saat ini belum maju karena masih banyaknya pihak yang memilih prinsip ketidaksetaraan yang secara tidak langsung melakukan perbuatan yang menguntungkan diri sendiri (Shidarta, 2006).

Berkaca pada konsep di Negara Republik Indonesia men ganut keadilan sosial. Kebanyakan masyarakat saat ini lebih aktif dengan keadilan sosial karena banyak yang lebih bertingkah laku tidak adil terutama dalam pembagian listrik ke rumah - rumah. Tidak adil disini berarti tidak mematuhi peraturan atau hukum po sitif yang berlaku, contoh yang terjadi dan sudah banyak masyarakat yang perhatikan. Kasus pemadaman listrik yang membuat banyak masyarakat jengkel dengan perusahaan PLN namun jika lebih ditelusuri lagi banyak pihak pekerja khususnya pekerja lapangan yang dengan berbagai alasan tidak memberitahu masyarakat tentang pemadaman bergilir ini.

Berbicara soal perlindungan konsumen erat kaitannya dengan hak, bagaimana tidak jika seseorang tidak mendapatkan haknya maka seseorang termasuk tidak mendapatkan keadilan. Namun hak dapat di dapat seseorang jika sudah melaksanakan kewajibannya dan secara langsung mempertanggungjawabkan kewajiban yang dilaksanakannya. Hak seorang sebagai konsumen tentunya berhak mendapatkan perlindungan dari pemerintah salah satu tindakan $\mathrm{p}$ emerintah dalam melindungi konsumen tentu dengan membuat undang - undang perlindungan konsumen. Tindakan represif dan preventif dilakukan demi mencegah terjadi hal yang tidak diinginkan dan tidak terjadi tindakan diluar hukum positif yang berlaku (Budiartha, 2016).

Berkaitan dengan perlindungan konsumen 
pihak PLN mengakut telah memprioritaskan listrik bagi masyarakat namun kejadian di lapangan berbeda dari pelayanan yang ada di PT. PLN. Wawancara dengan salah satu warga yang merasa dirugikan de ngan pemadaman yang dilakukan PT. PLN (Persero) UP3 Bali Selatan adalah Bapak Rudi Arthana beralamat di Jl. Tukad Citarum, beliau mengatakan:

"tidak ada pemberitahuan apa-apa tentang pemadaman listrik bergilir posisi saya memiliki balita dan butuh cahaya lampu, entah dari pihak kantornya yang tidak memberitahukan atau pekerja lapangan yang tidak meneruskan perintah atasannya" (Wawancara pada tanggal 20 maret 2021)

Berkaitan dengan komentar negatif dari salah satu pelanggan PLN UP3 Bali Selatan penulis mewawancarai bapak Putu Agus Cipta Kusuma mengatakan: "berkaitan dengan pemberitahuan kepada masyarakat terkait pemberitahuan pemadaman listrik kami selaku atasan sudah memberitahukan kepada karyawan agar tidak terjadi salah komunikasi dengan masyarakat terutama masyarakat yang ada di

jalur bali selatan khusu snya daerah panjer karena disana pusat perkantoran dan aktivitas masyarakat. Pemadaman sendiri dilakukan biasanya mulai pukul 09.00 sampai 15.00 itupun dilakukan sangat jarang guna menstabilkan arus listrik yang tersebar ke berbagai wilayah di Bali Selatan. Kesalahan komunikasi dengan pekerja lapangan merupakan kesalahan dari kami pihak PLN dan kedepannya agar tidak terjadi kesalahan serupa demi kebaikan bersama." (Wawancara pada tanggal 20 maret 2021)

Sebagai pelaku usaha, tentunya PLN berupaya menghindark an keluhan-keluhan dari pelanggan sebagai bentuk kewajiban mereka. Dengan menginformasikan rencana pemadaman yang akan dilakukan, diharapkan pelanggan akan memaklumi. Menurut Bapak Afriansyah selaku Supervisor Operasi UP3 Bali Selatan, "Ketika pemadaman berlangsung, seringnya pelanggan yang komplain sekitar daerah kota, mungkin dari perbedaan latar belakang pendidikan dan karakteristik mereka, karena untuk warga pedesaan biasanya akan memaklumi pemadaman listrik. Banyak pelanggan kota yang mengeluh karena tidak dapat pemberitahuan dalam bentuk apapun, padahal sesuai surat yang keluar, surat tersebut sudah terkirim ke kantor desa atau kelurahan masing -masing dan tidak hanya itu, kami juga sudah mengiklankan di radio dan menginformasikan melalui pesan seluler" (Wawancara pada tanggal 20 maret
2021).

\section{Upaya Hukum Yang Dapat Dilakukan Oleh Konsumen Listrik Bila Terjadi Pemadaman Listrik Sepihak Oleh PT. PLN Persero UP3 Bali Selatan.}

Terjadinya pemadaman listrik secara sepihak oleh PT. PLN Persero UP3 Bali Selatan memang kesalahan perusahaan namun jika lebih ditelusuri terdapat kesalahan komunikasi terutama pada pekerja lapangan yang bertugas memberitahu pemadaman listrik bergilir pada masyarakat. Kesalahan kecil seperti ini menjadi besar karena banyaknya pihak ya ng merasa dirugikan terutama masyarakat selaku konsumen. Masyarakat menuntut diberikan sanksi kepada PT. PLN Persero UP3 Bali Selatan agar tidak lagi melakukan kesalahan.

Sanksi sendiri memiliki makna dan arti yang berbeda - beda dan sesuai peraturan yang dibuat pemerintah. Penjabaran sanksi sebagai berikut (Hamzah, 1993):

\section{Sanksi Pidana}

Merupakan sanksi yang paling memberikan efek jera diantara sanksi lainnya, hal ini ditunjukan dari hukuman yang diterima bervariasi seperti menetap di penjara dan melakukan kegiatan yang ada di rumah tahanan selain itu memberikan buruk citra sendiri dan keluarga karena kedapatan melakukan perbuatan pidana.

\section{Sanksi Perdata}

Sanksi perdata biasanya melibatkan konflik antar masyarakat selaku konsumen dan perusahaan PLN sebagai perusahaan yang tidak memberitahukan pemadaman listrik kepada masyarakat hal ini membuat masyarakat meminta ganti rugi.

\section{Sanksi Administratif}

Sanksi ini berkaitan dengan pemerintahan semisal pelanggaran lalu lintas, akibat daripada tidak membayar pajak dan masih banyak lagi pelanggaran yang membuat seseorang harus mengganti rugi pada negara karena kelalaiannya.

Dalam mempertanggungjawabkan kesa lahan yang sampai membuat terjadinya kerugian pada masyarakat selaku konsumen pihak PLN PERSERO UP3 Bali Selatan sesuai dengan pengaturan pemerintah tentang perlindungan konsumen, harus mengganti kerugian yang diderita konsumen dan dalam kasus pemadaman li strik secara sepihak maka 
dituntut untuk mengganti rugi atas kesalahan yang dilakukan pekerja lapangan tersebut. Pemerintah sudah menghimbau berkali - kali tentang pemadaman listrik harus disampaikan terlebih dahulu kepada masyarakat karena jaman sekarang listrik sudah sebagai kebutuhan pokok yang menunjang produktivitas masyarakat dan guna meminimalisasikan kerugian konsumen yang berujung ganti rugi serta sanksi lain yang nantinya memberatkan pihak PLN PERSERO UP3 Bali Selatan. Terlebih terjadinya kesalah an yang dilakukan pihak PLN yang sampai membuat kerugian konsumen dapat membuat nama perusahaan sendiri menjadi tercemar dan dapat mengurangi permintaan masyarakat terkait listrik berlangganan.

\section{Simpulan}

konsumen memiliki hak atas kenyamanan, keamanan, dan keselamatan dalam mengkonsumsi barang dan/atau jasa. Sementara dalam UU Ketenagalistrikan disebutkan bahwa konsumen berhak mendapatkan tenaga listrik secara terus menerus dengan mutu dan keandalan yang baik. Maka sudah merupakan kewajiban PT PLN (Persero) UP3 Bali Selatan sebagai pemegang izin usaha penyediaan tenaga listrik, untuk menyediakan tenaga listrik yang memenuhi standar mutu dan keandalan yang berlaku. Apabila pemadaman listrik yang terjadi kura ng dari standar pelayanan yang telah ditetapkan oleh Pemerintah, konsumen berhak mendapat ganti rugi.

Upaya yang dapat dilakukan konsumen apabila terjadi pemadaman listrik sepihak oleh PT PLN (Persero) adalah dengan memberikan pengaduan kepada PT PLN (P ersero). Namun bila hasil upaya awal tersebut dirasa masih kurang memuaskan, konsumen dapat mengambil upaya hukum yakni penyelesaian sengketa melalui pengadilan atau diluar pengadilan berdasarkan pilihan sukarela para pihak yang bersengketa.

\section{Daftar Pustaka}

Abdullah, J. (2010). Aspek Hukum Dalam Bisnis. Kudus: Nora Media Enterprise.

Ahmad, B. (2008). Metode Penelitian. Bandung: Pustaka Setia.

Budiarta, I. N. P. (2016). Hukum Outsourcing. Malang: Setara Press.

Hamzah, A. (1993). Sistem Dan Pemidanaan Di Indonesia. Jakarta: Pradnya Paramita.

Nasution, A. Z. (2003). Hukum Perlindungan
Konsumen, Cetakan Pertama. Jakarta: PT. Raja Grafindo Persada.

Shidarta. (2006). Hukum Perlindungan Konsumen Indonesia. Jakarta: Grasindo. 